Etnográfica

Revista do Centro em Rede de Investigação em Antropologia

vol. 14 (1) | 2010

Vol. $14(1)$

\title{
Identidade e pertença: disposições morais e disciplinares em um grupo de jovens
}

Identity and belonging: moral and disciplinary dispositions in a group of youngsters

\section{Mauro Guilherme Pinheiro Koury}

\section{(2) OpenEdition}

\section{Journals}

Edição electrónica

URL: https://journals.openedition.org/etnografica/148

DOI: $10.4000 /$ etnografica. 148

ISSN: 2182-2891

\section{Editora}

Centro em Rede de Investigação em Antropologia

\section{Edição impressa}

Data de publição: 1 fevereiro 2010

Paginação: 27-58

ISSN: 0873-6561

\section{Refêrencia eletrónica}

Mauro Guilherme Pinheiro Koury, «Identidade e pertença: disposições morais e disciplinares em um grupo de jovens», Etnográfica [Online], vol. 14 (1) | 2010, posto online no dia 21 outubro 2011, consultado o 10 fevereiro 2022. URL: http://journals.openedition.org/etnografica/148 ; DOI: https:// doi.org/10.4000/etnografica. 148

\section{(c) (i) (9)}

Etnográfica is licensed under a Creative Commons Attribution-NonCommercial 4.0 International License. 


\title{
Identidade e pertença: disposições morais e disciplinares em um grupo de jovens
}

\section{Mauro Guilherme Pinheiro Koury}

\begin{abstract}
Este artigo busca compreender o sentido de pertença e sua relação com os códigos da confiança e lealdade, conceitos aqui entendidos sob a ótica do medo da traição ou da insegurança individual de não alcançar os ideais do grupo estudado. A pesquisa desenvolveu-se junto a um grupo de jovens que se autodefine como um grupo de apoio e afirmação dos jovens de bairros populares da cidade de João Pessoa, Paraíba, Brasil. O objetivo deste estudo foi o de perceber o processo organizativo interno do grupo e as redes vinculares que dão sustentáculo e base de apoio à sociabilidade grupal.

PALAVRAS-CHAVE: identidade, confiança, lealdade, disposições morais, disposições disciplinares, pertença.
\end{abstract}

\section{INTRODUÇÃO}

Este artigo busca refletir sobre os sentidos e as fronteiras da pertença grupal a partir da análise das disposições morais e disciplinares e das estratégias de amizade e sociabilidade vivenciadas por um grupo de jovens habitantes de bairros populares da cidade de João Pessoa, Paraíba, Brasil. Esse grupo de jovens é chamado, aqui, pelo nome fictício de Delta, autocaracterizado como uma comunidade de apoio e afirmação dos jovens de bairros populares da cidade de João Pessoa.

$\mathrm{O}$ artigo procura perceber o processo organizativo interno do grupo e das redes vinculares estabelecidas, que formam e oferecem as bases da sociabilidade grupal, a partir da análise de um conjunto de sentimentos e emoções partilhados entre os membros do grupo Delta. A confiança, a lealdade, a fidelidade e a gratidão, bem como as noções de segredo, dúvida, traição e deslealdade, são categorias que ajudarão a perceber o jogo de trocas simbólicas efetuadas pelos parceiros em interação, bem como a manutenção de um padrão organizativo 
interno e de controle social dos seus membros. O esforço analítico aqui desenvolvido, por fim, configura o valor e as bases compreensivas de uma abordagem antropológica que dê conta das dimensões sociais das emoções nas ações e processos de criação humana. ${ }^{1}$

O encontro com o grupo Delta deu-se por acaso. Foi um desses acasos importantes, ocorrido no momento em que o autor buscava contatos que permitissem a sua entrada nos bairros da capital paraibana para estudar a sociabilidade e os medos corriqueiros e sua relação com a cidade de João Pessoa no imaginário dos seus habitantes (Koury 2008). O autor estava procurando meios de se adentrar nos bairros populares da capital paraibana quando se aproximou de alguns jovens, estudantes da Universidade Federal da Paraíba (UFPB) que moravam em bairros considerados estratégicos para a pesquisa sobre medos e cidade então em desenvolvimento e por ele coordenada. Estes jovens se interessaram em inserir o pesquisador nos seus bairros, apresentá-lo a alguns moradores e descreverem as suas visões dos locais de moradia, desde as relações com os vizinhos à vivência nas ruas, o próprio bairro em geral e as relações que, na sua opinião, este mantinha com os demais bairros da capital, entre outros assuntos. Logo nas primeiras conversas, o autor foi envolvido por um novo elemento que começava a aparecer de forma cada vez mais clara nos depoimentos dos jovens: alguns deles faziam parte de um grupo que tinha como intenção primeira prestar apoio aos jovens da periferia, e era através do olhar do grupo, enquanto movimento organizativo, que falavam sobre o bairro, seus moradores e o trajeto e relações dos jovens, ou da imagem dos bairros onde residiam nos demais bairros da capital. A forma como falavam, o sentido da palavra assumida no relato das características dos jovens moradores de bairros populares de João Pessoa ou para discursar sobre eles e o movimento Delta, levou o autor a se interessar por saber mais sobre o grupo. Parecia, e isso se concretizou logo após as primeiras análises, que a vivência proposta pelo grupo constituía uma série de questões importantes para a análise dos medos cotidianos e sua relação com a sociabilidade que movimentava a sua pesquisa maior. Deste modo, solicitou aos jovens com quem iniciara o diálogo e aos outros que foram se juntando, por apresentação, no decorrer das conversas prolongadas que iam acontecendo com maior assiduidade, que discutissem a proposta de narrarem o processo formativo do grupo, o sentido e o papel

l Não é possível no escopo deste trabalho fazer um balanço sobre o conceito de emoção e discutir a gestão das emoções e as estratégias de expressão emocional entre os Deltas de forma mais aprofundada. Para um estado das artes da sociologia e da antropologia das emoções, são indicados ao leitor os textos de Koury (2004), Coelho (2006), Abu-Lughod e Lutz (1990) e Scheff (2001). Para a análise dos conceitos de "gestão das emoções" e "estratégias de expressão emocional", o leitor é remetido aos textos de Douglas Hollan e J.C. Wellenkamp (1996), de interessante veio na antropologia psicológica, e Ekman (1993), Hochschild (1997, 2003), Schwarz (2002), na sociologia e na antropologia das emoções, entre outros. 
desempenhado pelo movimento no apoio aos jovens de periferia, nas trocas simbólicas e na práxis Delta, interna e externa ao movimento, enfim, que permitissem ao autor o estudo dos Deltas como grupo. Alguns dias depois alguns jovens Deltas trazem a resposta positiva e ao autor é permitido freqüentar o mundo Delta.

Começa, então, um processo investigativo e compreensivo sobre o movimento em seu todo e os anseios dos jovens que dele fazem parte. O sentido de construção do movimento passa a ser transmitido ao autor, em inúmeras e memoráveis entrevistas, relacionado intrinsecamente com a constituição do grupo e de cada membro como um ser no e para o mundo, seus temores, seus desejos, as curvas de vida de cada um, estratégias de sobrevivência pessoal no grupo e fora dele, enfim, em torno da magia e do encantamento proporcionados por jovens na luta pela constituição de um modelo social que amplie os elementos de dignidade do ser humano e de intervenção na realidade, como prática e como sentido de confiança e auto-afirmação.

Este processo resultou em uma pesquisa sobre os Deltas e o trabalho de campo se adentrou por dois anos, entre 2001 e 2003, em que o autor teve acesso a todos os membros ativos do grupo e os agora consultores, entrevistando-os demoradamente, através do relato de suas histórias de vida antes e depois da entrada no movimento, e sobre a formação do grupo e as relações de cada membro com este e com os outros de fora do movimento. Nesses dois anos, o autor também freqüentou as diversas reuniões informais e formais do movimento, presenciou o rito de entrada de novos adeptos e acompanhou algumas crises pessoais e coletivas do grupo Delta. Sobre estes fatos, suas impressões e os seus achados, discutiu no coletivo e com cada membro em particular, permitindo novos aprofundamentos sobre o conhecimento do grupo. Esta pesquisa resultou em um livro (Koury 2006) sobre sociabilidade entre jovens no urbano contemporâneo brasileiro: o livro foi depois enviado pelo autor e discutido com os Deltas. É interessante frisar que, mesmo após o término da pesquisa e a entrega dos resultados aos Deltas, o autor não finalizou seus contatos, vez ou outra é procurado por membros individuais para relatarem suas novas experiências, conquistas e frustrações.

O movimento Delta atua, principalmente, em bairros situados próximo ao centro da cidade de João Pessoa, embora afirmem possuir, em número menor, membros distribuídos por outros bairros populares da capital. ${ }^{2}$ É formado por

2 São jovens recrutados em toda a cidade, mas, principalmente, dos bairros pobres mais próximos do centro da cidade: Ilha do Bispo, Varadouro, Alto do Mateus, Roger, Tambiá, Cidade Padre Zé, Mandacaru, entre outros. Os Deltas formam um grupo pequeno, em torno de cem membros, tendo uns sessenta atuando diretamente e o restante como "consultores" (os que têm mais de 30 anos) e que só interferem no movimento quando acionados pelos que estão na ativa, dando conselhos e mostrando caminhos. As propostas e as metas são discutidas pelos membros na ativa em assembléias e as resoluções tomadas a partir da unanimidade nas votações. 
jovens de ambos os sexos de uma faixa etária dos 15 aos 30 anos de idade. É verdade que alguns membros chegam a ter uma idade mais elevada do que 30 anos e, embora não deixem a militância, passam a ter uma presença mais simbólica do que efetiva no grupo, servindo como consultores ou conselheiros para problemas internos ou externos do movimento, ou como memória social e em relação aos princípios e ideário Delta. ${ }^{3}$

São jovens com uma história de vida difícil e uma presença conturbada no mundo, seja por questões ligadas a problemas econômicos ou familiares, seja por problemáticas de fundo social, afetivo ou emocional. A entrada no movimento Delta marca um corte na vida de cada membro. ${ }^{4} \mathrm{~A}$ distinção entre o

3 Os Deltas tiveram origem há um pouco mais de dez anos na ação evangélica protestante de um dos ramos da Igreja Batista na cidade de João Pessoa. Atualmente, apesar desta base original, gostam de afirmar que não são mais um braço evangélico da Juventude Batista, mas que são jovens que atuam nos bairros periféricos de forma independente no intuito de "salvar" rapazes e moças "em desespero, ou que estejam sem objetivos e sem rumo na vida por várias razões...", conforme o depoimento ao autor de um dos membros sobre os objetivos dos Deltas (entrevista concedida em 15 de janeiro de 2002). A presença batista é forte nos termos usados no cotidiano do movimento, quer quando tentam explicar suas ações e metas, quer no conjunto de relações entre si, onde se usa muitas citações bíblicas e muitas atitudes da moral protestante para espelhar a ação pessoal e grupal. Não são, contudo, um grupo batista. Durante a pesquisa de campo sobre os Deltas, o autor se inseriu em várias comunidades jovens batistas e de outras igrejas evangélicas em João Pessoa, para entender o próprio movimento estudado, e não encontrou eco nessas outras comunidades de ação evangélica. Pelo contrário, muitos dos jovens militantes de pastorais da Juventude Batista se mostraram interessados em conhecer os Deltas, mas não foi possível ao autor realizar esta aproximação. Quando colocada ao grupo esta solicitação de outros jovens evangélicos, aquele se manteve reticente, tendo o autor que reconquistar a confiança do grupo para dar continuidade à pesquisa, e, muitas vezes, foi afirmado de modo enfático: "os Deltas são um movimento independente, que busca orientar jovens para o caminho do bem", e "os membros Delta são produtos do próprio movimento..." e "novos membros são conseqüência de sua expansão..." (entrevista ao autor em 25 de setembro de 2002).

4 Os Deltas são recrutados, principalmente, entre a classe média baixa da cidade de João Pessoa. São jovens cujos pais saíram do interior do estado da Paraíba entre os anos de 70 e início de 80 do século passado para procurarem emprego ou uma vida melhor na capital. A partir de 1970 e até o início dos anos 2000, a cidade de João Pessoa triplicou sua população, passando de quase $200 \mathrm{mil}$ para mais de 600 mil habitantes. As dificuldades de emprego, a instabilidade socioeconômica dos pais, a cobrança para que os filhos contribuam economicamente para fazer frente aos gastos familiares, a falta de perspectiva e o futuro incerto povoam os depoimentos dos jovens membros da comunidade Delta. Os Deltas têm muito em comum, assim, com outros movimentos afirmativos de juventude no Brasil. O seu público é o mesmo: rapazes e moças pobres do Brasil urbano. Tem muito a ver, inclusive, com outros tantos movimentos jovens da própria cidade de João Pessoa, com base religiosa ou não. Os Deltas trazem a particularidade, que o autor não encontrou em outros movimentos, de uma ação igualitária entre os seus membros: da negação em discurso de qualquer hierarquia no movimento. Foi isso que atraiu o olhar do pesquisador. Até que ponto a confiança, a confiabilidade, o igualitarismo evocado se realiza na prática dos membros e do movimento? Como a comunidade moral Delta enfrenta a confiança no outro e que tensões são encobertas no receio de traição? E como é resolvida a tensão e afirmada a prática igualitária e a comunidade moral Delta? Este artigo busca entender no discurso Delta os termos em que se assenta a confiança na conformação moral do grupo e de seus membros. Para maior aprofundamento sobre o grupo, o autor remete ao livro O Vinculo Ritual (Koury 2006), onde melhor explora a questão. 
antes e o depois de pertencer ao grupo é fundamental para a caracterização do significado da presença do grupo na vida de cada um, bem como do sentido atribuído ao grupo, em sua totalidade, pelos que dele fazem parte.

As amizades com e entre os membros do grupo ou a mudança na qualidade e estilo de vida após a adesão ao grupo perfazem uma espécie de renascimento para o mundo social e psicológico de cada membro. Este fato é fundamental para a compreensão da cultura política Delta de inclusão social dos seus membros e de vinculação interna de cada membro ao grupo.

As novas amizades e a sua intensidade na biografia do jovem revolucionam o cotidiano e as perspectivas do novo membro, a ponto de causar uma espécie de ruptura simbólica entre o antes e o depois de sua adesão ao grupo. Após a entrada no movimento, o novo membro ressurge socialmente como um ser mais integrado ou que busca um melhor papel na sociedade em torno. Em termos psicológicos, sente-se mais ajustado e confiante em si mesmo pela assunção da pertença ao grupo Delta.

Esses jovens normalmente retornam à escola, muitos hoje são já estudantes de terceiro grau ou já formados e atuantes em diversas profissões; voltam a ter um melhor relacionamento com a família, com os amigos, com os companheiros, com os filhos e consigo mesmos; passam a deter um sentimento de adesão, de missão ou de conquista perante o mundo. São jovens que procuram sair de si enquanto problemática existencial e que abrem para si um processo de atuação que vai da busca de conquista de um espaço social até o esforço de ampliação da rede Delta entre os jovens de fora do movimento, tendo sempre a noção do que foi o processo antes da adesão, assim como o sentido e a força da sua construção social enquanto membro singular e enquanto coletividade.

É o esforço de constituição de um movimento afirmativo e de apoio que interessa analisar neste artigo, assim como as suas conseqüências para a ação e para a construção social. As tensões resultantes, os impasses entre as ações individuais e coletivas decorrentes, o significado e a vivência prática do pertencer ao movimento, o significado da adesão na vida de cada um e as conseqüências desta adesão nas relações com os demais membros e com os de fora do grupo, o ideal de ser e o medo de não o conseguir, vivido internamente por cada membro e nas práticas relacionais grupais, o uso e os sentidos dos termos "confiança" e "lealdade" na vida de cada membro e nas relações grupais, enfim, organizam a problemática deste artigo, aqui discutida a partir da análise do movimento Delta.

\section{PERTENÇA E CONFIANÇA}

A confiança e a confiabilidade são elementos categoriais importantes para a definição de pertença ao grupo Delta. Podem se espelhar tanto internamente, no sentimento de solidariedade e irmandade, quanto externamente, através da 
visibilidade de ações e comportamentos sociais marcadores de singularidades e especificidades que demarcam o grupo de jovens frente aos demais e à sociedade onde se encontram inseridos, em geral.

Os dois termos levam também a pensar a problemática do estranhamento, uma categoria necessária à constituição de uma sociabilidade e de uma individualidade quaisquer. Se o estranho intimida e provoca reações sociais que visam a indiferença e sua exclusão (Goffman 1985; Heller 1983; Simmel 2005; Koury 1998), também provoca reações de proximidade e busca de semelhança que levam à assimilação e à composição conjunta a uma dada esfera simbólica e discursiva. O sentido e a vivência da noção de confiança, deste modo, constituem um aspecto do medo do outro e da sua ultrapassagem, fundamentando códigos de semelhança onde a confiabilidade é sentida como uma prática entre iguais.

Confiança, então, é uma atitude que permite àqueles que a possuem, ou põem em prática, uma espécie de segurança íntima de procedimento: o outro passa a ser visto como uma extensão ou prolongamento do eu. É um lugar de familiaridade, onde os laços afetivos são intensos, onde a crença no valor do grupo parece sobressair ou sobrepor-se aos diversos membros que dele fazem parte, ao mesmo tempo que assegura um espaço de diferenciação de cada membro em relação à sociedade em geral. No processo de integração no coletivo, o indivíduo que se sente pertencendo ao grupo sente-se, também, como que encontrando a sua face no social. Ele se torna membro de um grupo e, nessa transubstanciação, parece adquirir um sentido de individualidade pessoal, tornando-se sujeito de fala e de ação frente aos demais.

A confiabilidade, por seu turno, traduz-se na ação de conceber ou de conceder confiança. É um ato que requer a aceitação das regras ou códigos de conduta que movimentam as interações entre os diversos membros e que fazem do grupo uma realidade sui generis, ${ }^{5}$ o que permite aos membros uma concepção sobre a ação de todos e de cada um no mundo exterior e sobre os pares ou parceiros da intensa e constante interação no interior do grupo.

Esta concepção permitida pela confiabilidade revela-se, também, como um ato de dupla concessão de confiança: de um lado, pela crença de que o parceiro é confiável e requer confiança; de outro, por se ser, ao mesmo tempo, sujeito de confiança. Isso permite aos outros elementos do grupo situar o jovem membro nos códigos de confiança que regem e dão sentido às formas comunitárias que orientam o sentido de pertença grupal e, assim, torná-lo passível de confiança, atestando confiabilidade às suas ações e ao sujeito em si mesmo.

A confiança e a confiabilidade, neste sentido, são conceitos dinâmicos na vida ordinária do grupo, pois levam os seus membros diuturnamente a se 
mostrarem sujeitos confiáveis, a demonstrarem confiança pela e na pertença e a concederem confiança enquanto crédito pessoal ao outro ou do outro em relação a cada um dos membros e a cada membro em relação a si próprio. Esta dinâmica pode ser sentida, por exemplo, na fala de um rapaz de 25 anos que informa ser um sujeito de sorte por fazer parte do grupo:

[...] eu sou um sujeito de sorte, pois era um nada nessa vidinha de merda até que fui lançado pro conhecimento dos meus camaradas e fui me tornando um Delta. Aqui eu me sinto melhor do que na minha casa, os camaradas são a minha verdadeira família, confio neles [para] tudo o que acontece comigo e sei que posso contar com eles pra qualquer parada. ${ }^{6}$

Neste depoimento se pode sentir a importância do grupo na vida do informante. A descoberta e o processo de adesão parecem indicar uma modificação positiva na vida do sujeito, dando um sentido pessoal ao mundo ao redor, aos companheiros de grupo e a si mesmo. No pertencer, no sentir-se integrado numa comunidade de interesses, o jovem encontra o liame da transmutação de "um nada qualquer" para um sujeito com sentido na vida.

Acontece uma espécie de nascimento para o mundo através do grupo e, simultaneamente, o florescimento de si mesmo como pessoa que possui um lugar no mundo, de onde fala e por onde se move. ${ }^{7}$ Esse lugar é uma espécie de lugar de visibilidade, através do qual o sujeito se torna existente ou adquire existência para os outros e para si próprio. É um lugar de duplo significado: de um lado, um lugar de semelhança, onde a identificação com os demais membros cria um sentido de familiaridade e uma rede de afetos que tornam o indivíduo pessoa, pela confiança e confiabilidade aferida e doada pelas partes em relação; de outro lado, é como um lugar de diferenciação, a partir do qual o sujeito pode se tornar visível como individualidade, é a marca de uma personalidade que possibilita a fala e a comunicabilidade com outros diferentes.

Assim, ser um Delta é mergulhar em um universo relacional, composto por pessoas confiáveis e em que se depositam credo, crédito e lealdade e, ao mesmo tempo, em um universo de individualização que permite ao sujeito apresentar-se como diferente aos outros sociais e, a partir desta diferença, estabelecer os limites e ações possíveis das trocas sócio-simbólicas. Mais ainda, o sentido de pertença advindo do mergulho no universo relacional do grupo permite ao sujeito individual sentir-se pessoa que acredita e é acreditada, mas também

6 Entrevistado no início do mês do abril de 2002. O informante cursa o primeiro ano do ensino médio à noite, na escola estadual do bairro onde mora, trabalhava como entregador de pizza, foi despedido e vive de pequenos biscates como motoboy. É solteiro e mora com os pais, mas tem uma filha de dois anos e meio que mora com a mãe em uma das cidades da grande João Pessoa. Neste artigo se procurou manter a construção verbal, os vícios e as falhas de linguagem dos entrevistados.

7 Para a questão do renascimento identitário, ver, entre outros, Dubar (1997, 2000). 
sujeito de um discurso que evoca um lugar de origem e o torna visível através desse lugar, individualizando-o enquanto ser singular. ${ }^{8}$

O sujeito transmuda-se de um indivíduo qualquer para um indivíduo tocado por uma revelação, o que o singulariza junto aos outros indivíduos, grupos ou instituições sociais, e permite ao mesmo tempo olhar, sentir-se e tocar o mundo ao redor a partir da especificidade pessoal adquirida ao se sentir um Delta.

O sentido de pertencer, a sensação de estar pertencendo, de fazer parte, assim, parece evocar nos indivíduos tocados pela fé uma comunhão com os demais membros que se consubstancia em uma elevação do grupo acima de si próprio. Neste sentido, faz do indivíduo uma pessoa relacional que se encontra, se submete e se revela no e para o grupo.

O grupo é, deste modo, um conjunto de membros que se afirmam um. Cada membro vive o sentido da comunhão de interesses e vontades do grupo e nele advoga um sentido de similitude que o iguala aos demais membros, em uma comunidade de interesses e de compreensão do mundo. Lá se sente confiante e depositário de confiança.

A confiabilidade é o elemento principal de garantia de pertença e sociabilidade entre os membros e aquilo que torna os Deltas uma comunidade solidária e sólida. $\mathrm{O}$ sentido de pertencer, assim, trazido à luz pela categoria de confiança, advoga um sistema moral que paira acima dos indivíduos em relação, tornando-os uma mesma pessoa, coletiva, e dando-lhes um sentido prático racional de olharem para si mesmos e para os outros como pessoas tocadas pela revelação - a revelação de ser Delta, de ser um apenas por pertencer ao conjunto, de ser, durkheimianamente falando, um indivíduo social por ter sido produto da criação deste social, isto é, por só nele e através dele adquirir sentido pessoal:

Minha relação com ser um Delta é uma relação de me saber respeitada, de me achar que faço parte de uma coisa grande que me faz respirar melhor, que me faz querer 'tar junto, que me faz me sentir gente. Eu era uma menina normalzinha, ninguém reparava em mim, vivia com medo de tudo e de todos, o mundo parecia ruim demais e medonho demais. Quando eu comecei a me aprochegar na turma fui vendo que eu era muito pequena, muito mesquinha, só via o meu umbigo e os outros eram o perigo; aí fui me soltando, fui fazendo confidências com uns colegas, fui sendo também procurada para me contarem problemas e fui vendo que as coisas poderiam ser diferentes, fui ganhando confiança e vendo que havia gente leal e que me dava valor. Aí me aprocheguei e quando vi já era uma Delta. Já estava sendo uma Delta, 
eu já fazia parte e acreditava e depositava confiança no grupo e nos meus camaradas e me sentia protegida, amada e querida por eles. ${ }^{9}$

Como a primeira narrativa, este depoimento fala da revelação e da modificação da vida desta jovem com a aproximação e posterior adesão ao grupo. Fala da confiança nela depositada e na confiança por ela depositada no grupo como um dos elementos significativos da mudança de percepção da vida em geral e da sua vida em particular, antes e depois da opção de entrar no grupo. Fala ainda do amor, de se sentir protegida, da lealdade e da descoberta do valor pessoal e da valorização da sua pessoa, advindos da sua subsunção ao grupo como um sistema moral e simbólico.

Confiar é, portanto, uma categoria analítica que remete a outras duas categorias compreensivas. A primeira é o sentimento de proteção, de se sentir protegido e proteger. A segunda, corolário da primeira, diz respeito ao sentimento de lealdade. Ser leal e obter lealdade em troca são o fundamento da proteção, do sentir-se seguro e do ter segurança, que remete, por sua vez, aos espaços construídos de confiança e confiabilidade no, para e pelo grupo.

\section{SEGURANÇA E LEALDADE}

O sentimento de lealdade para com os outros membros do grupo funda um código de conduta que permite a esses jovens sentirem-se Deltas, isto é, pertencentes a uma comunidade moral onde os valores e hábitos são balizados através da fé depositada ou esperada do outro membro do grupo, no sentido de permitir a confiança e de exercer a confiabilidade necessária à segurança de cada um. A revelação de poder confiar e ser alvo de confiança permite ao grupo tornar-se uma comunidade de valores morais, onde a segurança e a lealdade são condições de apropriação e manutenção de uma prática social e pessoal que assegura ao coletivo uma margem de independência em relação aos membros individuais e permite que cada um se revele como pertencente a este código de conduta moral e, através dele, se relacione consigo próprio, com os restantes membros e com os outros sociais de fora dos Deltas.

A segurança é uma categoria analítica associada à confiança. Nela se configura uma condição sobre o outro, ou sobre aquele ou aquilo em que se pode confiar, o que parece permitir um grau elevado de certeza sobre a conduta dos

9 Entrevista realizada em março de 2002, com uma jovem de 19 anos de idade que pertence ao grupo há três anos. Estudante do segundo ano do ensino médio noturno de um colégio municipal de um bairro próximo daquele onde mora, trabalha durante o dia como balconista de uma farmácia no centro comercial da cidade de João Pessoa. Solteira, namora atualmente um rapaz com que vinha conversando há algum tempo para sua aproximação e posterior integração no grupo de que faz parte. Mora com os pais, aos quais ajuda com as despesas mensais da casa. 
outros em relação, de convicção naquilo ou naquele com que o indivíduo se relaciona e de firmeza sobre a ação dos outros e do próprio sobre as possibilidades e extensão das respostas ao problema da confiabilidade e da confiança individual e grupal. É também um ato de afirmação.

O sentimento de segurança parece conter um espírito de corpo que leva os indivíduos envolvidos a se relacionarem entre si como pessoas que depositam nos outros relacionais, e em si mesmas, uma crença de irmandade e familiaridade a partir da qual é possível perceber o mundo, irmandade ou familiaridade afirmativas, como códigos de conduta em que ser considerado seguro e ter segurança na lealdade e confiabilidade do outro da troca são condições socialmente satisfeitas.

Estar em segurança, então, é se encontrar convicto, seguro ou certo da resposta do outro; é confiar no outro e nas próprias ações como trocas, ou como sinônimo de lealdade. Lealdade é a qualidade, ação ou procedimento de ser leal. De ser fiel e depositário de fidelidade, o que, por sua vez, está associado à honra ${ }^{10}$ e a conceitos como os de honestidade, sinceridade, franqueza e pureza de sentimentos.

Ser leal, neste sentido, é ser digno e honrado. É uma qualidade que encaminha o sujeito que a retém, a procura ou a deposita em alguém, para uma conduta de compromisso grupal ou com o outro. É um elo de reciprocidade. É uma expetativa de ser merecedor ou encontrar alguém que mereça e mantenha a consideração geral pela ação ou conjuntos de ações confiáveis. Fazer parte dos Deltas é, deste modo, ser fiel aos princípios morais do grupo e encontrar lealdade com e nos outros:

Uma vez me puseram à prova por uma besteira que circulou pelo grupo de que eu não era inteiramente fiel, disseram confiável, ao grupo. Me deram um caldo ${ }^{11}$ pra eu nunca mais esquecer. Eu tava entrando no grupo fazia uns poucos meses e me encontrava deslumbrado; só via o grupo, só me entendia pelo grupo, só fazia o que o grupo queria e coisa e tal. Mas, numa festa, eu dei pra comentar com uma menina, que não era propriamente do grupo, mas que andava com a gente, sobre o interesse de um camarada por ela e coisa e tal. Passei a noite conversando com ela sobre isso, na melhor das intenções de promover o camarada pra ela. Ninguém disse nada, ninguém

10 Para o sentimento de honra, ver a excelente coletânea de Peristiany (1968) e nela, com destaque, o texto de Bourdieu (1968). Ver também, para uma visão mais aproximativa da realidade brasileira, o interessante livro de Souza (2000).

Il "Caldo" é um termo usado pelo grupo e seus membros para designar uma atitude disciplinar de distanciamento e rejeição, por parte dos outros membros, daquele que não honrou os compromissos Delta. É uma forma de punição ou teste que pode ser administrada de vários modos: de uma simples advertência, um ou dois dias sem falar e literalmente ignorar o outro, alvo da ação disciplinar, também chamada de "dar um gelo", até o rompimento definitivo dos laços. 
deu um toque pra mim de que eu estava agindo errado, o camarada tava lá, eu mesmo chamei ele várias vezes pra ele se aproximar da menina, e ele tirava de fininho e coisa e tal. No outro dia me deram um gelo, ninguém falava comigo, eu me aproximava e os camaradas iam aos poucos saindo, ou se não saíam me ignoravam... Pensei que ia morrer, juro, de repente eu era tudo e de repente me vi um nada à esquerda, um bostão... ninguém dizia nada, me evitavam como se eu tivesse a peste. Fui pra casa, me tranquei no quarto, a cabeça aos pulos, uma dor de cabeça arretada, e como um menino chorei pra caramba, dormi e, no outro dia, resolvi tomar satisfação, saber o que tava acontecendo. Foi difícil chegar aos camaradas, mas já sabendo que fiz alguma merda que não sabia, tava querendo saber que merda era essa pra dar satisfação e resolver tudo aquilo. Não dava pra agüentar viver mais um dia sequer assim. Rodei pra lá, rodei pra cá, os caras fingiam não me ouvir, mas eu falava assim mesmo e ninguém dizia nada... Eu tava quase desistindo quando fui procurado por Porcão ${ }^{12}$ a mando dos demais camaradas. Falamos quase a noite toda, ele ouviu minhas interrogações e minhas angústias e ele falou do sentimento do grupo para comigo e do motivo que levou o pessoal a me olhar de banda. Me expliquei, ele deu uns tapas nas minhas costas e foi embora. No outro dia já havia uma certa descontração no ar, as meninas olhavam e riam e me acenavam ou caras começaram a se aproximar, e de noite a gente se reuniu no Ponto Seis, ${ }^{13}$ onde o camarada ofendido se aproximou, apertou a minha mão e me chamou de mano. E aí se acabou as horas mais horrorosas da minha vida, e, então, eu fui e me sinto aceito integralmente pelo grupo. ${ }^{14}$

Este longo depoimento serve para compreender o sentimento de lealdade como um dado de confiabilidade da pessoa no grupo. Os códigos de ação cotidiana servem como delimitadores do comportamento esperado pelos membros

12 Todos os membros do grupo possuem uma espécie de cognome, um apelido que, normalmente, diz respeito a uma característica física ou de personalidade do sujeito apelidado. Porcão é o apelido de um rapaz do grupo, gordo e de aparência suada e com muitas espinhas no rosto, membro dos Deltas. Refere-se a si próprio pelo apelido. O apelido parece assumir para ele uma espécie de marca registrada de sua individualidade e de sua aceitabilidade no grupo, bem como para todos os demais entrevistados que associavam o cognome dado a cada um a uma espécie de marca pessoal distintiva e de reconhecimento individual no grupo.

13 O Ponto Seis é um local de encontro da rapaziada do bairro. É uma praça no centro de um dos bairros em que o grupo se espalha, onde se joga conversa fora, se joga futebol e «se paquera as minas». O nome Ponto Seis é uma espécie de denominação do grupo para os locais de encontro só deles.

14 Entrevista realizada em maio de 2002, com um rapaz de 22 anos, solteiro, que mora com os tios desde que os seus pais morreram, quando tinha 10 anos. Parou de estudar quando terminou o segundo grau, hoje só trabalha vendendo verduras em um boxe do tio no mercado central de João Pessoa. Toca guitarra e tem uma banda que se apresenta nas festas do bairro e no culto da igreja evangélica que freqüenta. 
e um sinal errado torna-se uma ofensa moral. Essa ofensa pode levar a atitudes de rejeição do membro como um indivíduo que não honrou a confiança nele depositada pelo grupo em si e pelos membros particulares que perfazem o conjunto.

O desempenho necessário de um Delta passa, desta forma, por uma constante e contínua avaliação do grupo, pela qual os compromissos baseados na lealdade e na confiabilidade são checados e as advertências disciplinares dispostas de forma imediata através do "caldo" e do "gelo" dados aos indivíduos em prova. Esses dois instrumentos disciplinares são baseados na demonstração da invisibilidade do sujeito, da sua não existência e importância para o grupo como totalidade, uma demonstração de que é o grupo que permite e garante a visibilidade dos indivíduos nele imersos, já que sem o grupo não há o indivíduo.

Os membros em situação de "gelo", neste caso, são completamente ignorados pelos demais. Estes se comportam como se não existisse ninguém ao redor: não agridem verbalmente, não há agressões físicas, apenas uma demonstração da inexistência do outro. As aproximações do indivíduo sujeito a um "caldo" aos demais membros do grupo são apenas ignoradas, as rodas de conversa continuam ou se dispersam, passa-se pelo membro sob suspeita como se ele não existisse.

Os processos de individuação ou de anulação social do sujeito em relação ao grupo, provocados pela aparente quebra dos compromissos para com o todo, acontecem ritualmente. Com esse ritual se provoca a invisibilidade do membro perante o grupo, sob a forma de um "gelo" dado no outro em julgamento.

Neste ritual, o grupo passa a idéia de coesão interna através do isolamento do outro, em atos de absoluta quebra de interação com ele. A invisibilidade e inexistência do outro são demonstradas pela visibilidade e corporeidade do grupo, por sua coesão interna, movidas pelas regras de confiança e irmandade.

O ritual busca demonstrar para o grupo a idéia de segurança como um elemento necessário à manutenção do coletivo. É ela que permite a comunidade Delta se ver como Delta. A quebra da segurança, provocada por um desvio de conduta de um dos membros, se não for imediatamente controlada através de ações disciplinares, poderá levar o grupo à extinção, já que o movimento interno é mantido pela idéia de confiança e confiabilidade dos seus membros em relação ao grupo.

O ritual disciplinar também tem a função de demonstrar para o membro sob suspeita, ou pego em atitudes desviantes, que o grupo é maior do que as suas ações, que as regras de confiança conduzidas pelo grupo é que permitiram a existência do membro em julgamento e que o grupo, apesar das ações desviantes ou da quebra da lealdade, se mantém coeso, unido e seguro. 
No caso do membro em situação de "gelo", por outro lado, o isolamento parece provocar uma situação de morte simbólica, uma perda do sentido de pertença, um movimento interno de rejeição que leva à insegurança dos atos do indivíduo e a que ele perceba não ser ninguém sem o grupo. Esse membro é levado a uma atitude de querer reparar o erro, embora não saiba bem onde, quando e porque errou, e dá explicações ao grupo na busca de refazer uma trajetória de integração que o movimento de individuação, provocado pela atitude de quebra de sua confiabilidade perante o grupo, desfez.

O ritual disciplinar também tem uma função regeneradora. Apesar de invisível, o sujeito em individuação, ao gritar explicações, é ouvido e observado pelo grupo. Se conveniente, um membro é destacado para conversar com o sujeito em julgamento e sondar a possibilidade de refazer a ponte para o seu retorno ao grupo. Reconhecida a não intencionalidade da ação desviante e as boas intenções dos gestos ou atitudes que provocaram no grupo a sensação de deslealdade daquele que os promoveu, é construído um canal de reaproximação que redundará na reaceitação pelo grupo e no reconhecimento do membro sob suspeição como sendo, novamente, um Delta.

\section{DISCIPLINA, VERGONHA E ORGULHO}

A confiança e a confiabilidade, neste trabalho, só podem ser pensadas através do conceito de lealdade. Este conceito, por sua vez, parece requerer as noções de disciplina e segurança como pré-requisitos da análise. Os Deltas baseiam a sua constituição em um código moral segundo o qual a confiança depositada por todos uns nos outros e no grupo é fundamental para a existência deste no seu conjunto, como também é imprescindível para a conformação do caráter individual de cada membro.

O caráter moral identifica o semelhante pela familiaridade confiada aos membros do coletivo e, ao mesmo tempo, os diferencia como sujeitos no mundo, nas trocas necessárias com outros grupos e a sociedade em geral. Por outro lado, se o sentido atribuído pelo caráter moral oferece segurança a cada membro individual e à prática grupal, pela disposição da lealdade entre os membros e para com o todo, parece levar também a uma incitação constante de cada membro singular e de todos os membros quanto à adequação das práticas individuais ou grupais. Parece pairar no ar uma contínua advertência sobre como se comportar, o que se pode dizer e o que se pode calar.

Gestos, atitudes, expressões, ações ou reações são constantemente testados, sem que seja preciso um dispositivo específico para tal. Os dispositivos disciplinares existem, sim, como se viu acima, mas para casos comprovados de suspeição ou flagrante, o que leva a atitudes extremas de isolamento e à sensação de invisibilidade do suspeito através do "caldo" e do "gelo". O que se está discutindo aqui, porém, diz respeito às introjeções individuais sobre como 
ser um Delta, sendo as ações de cada um movidas pela presença constante de um forte sentimento de vergonha, ${ }^{15}$ do medo de ser acometido por atos que venham a ser considerados como não condizentes com a prática grupal.

A vergonha é um sentimento socialmente expresso que implica um compartilhar da emoção com todo um complexo grupal e sua rede relacional. Sentir vergonha tem o significado de ser alguém de crédito, alguém em quem se pode confiar e que pode ser considerado leal. Os conceitos de fidelidade e confiança permitem um plexo de segurança e conformidade individual assegurada pela vergonha como elemento constitutivo do caráter - caráter individual este que é coadunado com o caráter moral do grupo.

"Ter vergonha na cara" é, assim, o que distingue um sujeito disciplinado, no sentido de ser uma pessoa consciente de suas ações e compromissos para com o grupo e os outros relacionais. As ações individuais, deste modo, são pautadas pelo sentimento expresso de vergonha, como indicativo de caráter moral rígido e condizente com o elevado padrão de honradez exigido e orientado pelo grupo.

O orgulho de ser um Delta, deste modo, é orientado por um controle sobre as ações pessoais, tanto em relação a si mesmo quanto em relação aos outros membros individuais, quanto ainda em relação a todo o grupo. O disciplinamento moral é um elemento fundamental de garantia da continuidade do "eu" na relação grupal e na relação do grupo com os membros individualizados. Esta ação disciplinar imposta pelo próprio indivíduo relacional a si mesmo e exigida para todos no grupo é uma forma de reconhecimento do indivíduo no grupo e do seu auto-reconhecimento como pessoa singular a partir do grupo:

[...] tinha largado de estudar porque achava um saco grande. Trabalho desde os 15 anos para sustentar os meus filhos, desde que fiquei grávida a primeira vez, aos 14 anos, e meu pai me botou pra fora de casa. Minha avó me acolheu e eu moro com ela até hoje, mas como não tinha muitos recursos tive que ir pra batalha. O pai do meu primeiro filho se picou, nem registrou a criança nem nada. Depois tive outra gravidez, numa época em que eu tava muito doida e este, também, não tem pai. Fiquei na escola na marra, por insistência da minha avó, até terminar a oitava série. Aí não teve mais jeito, saí e saí mesmo. Agora só trabalho e deixei a vida doida que levava. Muito devo aos Deltas. Quando me aproximei eu tava no fim dos 18 anos e dei de cara com um cara que começou a conversar comigo e me dar atenção sem ir mais além do que isso... Foi ele que me levou aos Deltas e o pessoal me recebeu numa legal e eu comecei a ter uma turma e me valorizar e achar bom nisso e valorizar os outros. Que eu não precisava sair dando por

15 Para um aprofundamento sobre a emoção vergonha, ver, entre outros, Elias (1990, 1993), Harkot-de-la-Taille (1999), Koury (2003). 
aí para me sentir querida, que ser querida era algo diferente, não sei se tou me fazendo entender... Essa coisa de me sentir uma pessoa legal, de achar que eu posso ser útil e que as pessoas gostam de mim por ser eu mesma foi uma coisa que aprendi sendo uma Delta. Outra coisa que aprendi é que isso exige muita consciência e respeito pelos outros, pois o respeito por mim vem pelo respeito que passo para os outros... Aí aprendi a me controlar mais, a dizer só as coisas que devem ser ditas, e não sair dizendo tudo o que passava na minha cabeça oca. Aprendi também a ouvir e saber recolher o outro e a também procurar os outros Deltas pra me abrir e chorar e também rir. Tudo o que sou hoje devo aos Deltas e hoje me sinto uma Delta. Foi um longo aprendizado esse, pela vida que eu vinha levando antes, mas fui aprendendo e agora sou. Tenho confiança em meus camaradas e tenho a confiança deles. Me sinto útil e responsável; pra mim isso é ser uma Delta: saber manter os compromissos, saber me manter na linha e exigir isso dos do grupo, saber ouvir e ser ouvida, ser leal aos meus princípios, que são os princípios dos Deltas, e ser, sobretudo, controlada... ${ }^{16}$

Os elementos do discurso presentes neste depoimento são importantes para caracterizar o sentimento de ser Delta. A autoconfiança e a confiança no outro requerem um autocontrole sobre si mesmo e a exigência dele nos outros, o que demanda um disciplinamento constante por parte do indivíduo e por parte de todo o grupo. Esse disciplinamento, por sua vez, é embalado pela idéia de compromisso para com o grupo, que implica, também, uma obrigação para consigo próprio. O sentido de lealdade ao grupo implica um sentimento de fidelidade a si mesmo.

O sentido de pertença, de ser um Delta, é um exercício moral de autocontrole que estende e eleva o sentimento de pertencer à totalidade grupal e permite que o indivíduo se encontre como membro. Um membro é sempre especial por permitir o reconhecimento dos demais membros, por via do conjunto, e neles reconhecer-se como pessoa, um indivíduo relacional que tem compromissos e se sente comprometido e motivo de compromissos com os outros da relação. A lealdade a estes compromissos dá o significado da pessoa no grupo, enquanto singularidade, e oferece também o elemento de sua homogeneidade perante a totalidade, por se sentir pessoa, porque pertence e aceita, obedece e segue os princípios dos Deltas.

Ser um Delta, deste modo, não é um sentimento apenas subjetivo, mas implica uma objetividade que se expressa na consciência da necessidade do

16 Entrevista realizada em maio de 2002, com uma jovem de 24 anos, Delta desde os 19. Solteira com dois filhos, mora com a avó, trabalha em uma lanchonete situada na orla marítima de João Pessoa e estudou até a oitava série do ensino fundamental. Atualmente namora um dos membros dos Deltas e está pensando retornar aos estudos. 
autocontrole nas ações como membro do grupo. Esse autocontrole é movimentado pelas idéias de confiança, de confiabilidade, de compromisso e lealdade.

O autocontrole é uma forma disciplinar que faz com que o indivíduo introjete um conjunto de normas e valores norteadores de suas ações presentes e futuras. $\mathrm{O}$ autocontrole implica um tipo de racionalidade de ações segundo a qual a emoção é regrada através do(s) sentido(s) a ela atribuído(s) pela pessoa que a pratica e por aqueles que a ela reagem. A emoção deixa de ser pura subjetividade de expressões de sentimento para ser moldada e praticada pelos indivíduos e pelo conjunto societário através de seus micropoderes (Foucault 1979). Os compromissos morais para com o grupo, para com os outros e para com a pessoa mesma, deste modo, passam a ressignificar o caráter da ação social individual e grupal, e os indivíduos que nela se movem são sujeitos ao conjunto das normas e regras socialmente instituídas e vêem-se uns aos outros através deste complexo moral.

Ser um Delta, assim, é compartilhar sentimentos regrados pela confiança depositada no indivíduo e dele requerida. Essa é uma pátina de fino toque onde o sujeito caminha pelo sentimento de pertencer, moldado pela constante disciplina pessoal e grupal das suas ações. O reconhecimento do outro passa assim por uma idéia de redobramento (Sennet 2001: 191-199) onde parece existir uma identificação parcial do sujeito da ação com outro sujeito, imaginando o que ele imaginaria, mas conservando ao mesmo tempo os atributos individuais que o tornam pessoa.

Essa relação é delicada porque sujeita a interpretações e expetativas várias da ação ou da intenção do outro da relação ou do próprio sujeito da ação, o que tensiona a ação e aumenta a pressão pessoal e grupal sobre os sujeitos em cena. Isso proporciona, ao mesmo tempo, um aumento do autocontrole ou autodisciplina e um aumento dos mecanismos de segurança individual e grupal, como forma de defesa daquele que impulsiona a ação e do outro que é alvo da ação.

É também uma relação sempre tensa, porque movimentada por sentimentos de não correspondência das ações ao buscado e erigido pelo grupo. O grupo, deste modo, parece se situar além das ações individuais, esperando que os indivíduos a ele pertencentes sempre aprimorem o seu comportamento pessoal e suas atitudes em relação ao outro relacional.

É interessante notar que um dos sentidos figurativos da expressão "tenso", constante no Dicionário Aurélio de Língua Portuguesa, é "muito aplicado". A busca do acerto das ações e a tentativa de confiar e ser confiável torna tensa a relação entre os atores envolvidos. O receio de errar ou não ser bem interpretado pelo outro da relação provoca um movimento de aprimoramento das ações e um crescimento do exercício crítico sobre o outro e sobre si mesmo, que aparece no momento da observação e análise como um misto de obediência ou sujeição às normas e padrões morais do grupo e de disputa silenciosa sobre quem melhor exprime e aprimora os valores grupais. 


\section{PODERES, HIERARQUIA E SILÊNCIOS}

A disputa é silenciosa porque não é confessada ou não chega a ser afirmada por cada membro individual dos Deltas, muito embora o grupo promova uma espécie de pontuação das ações realizadas por seus membros e consideradas exemplares, que servirão de espelho para os demais. Cada membro busca se orientar, ou "guiar", na expressão do grupo, por essas ações-modelo que, por sua vez, se tornam motivo de orgulho para o grupo em geral e são contadas e exteriorizadas por todos como afirmação do ser Delta.

Em quase todos os depoimentos colhidos, as ações-modelo são contadas para exemplificar o espírito Delta. Nestes depoimentos, idéias de sacrifício pessoal, de enobrecimento do outro, da autodisciplina e rigor disciplinar são evocadas para exemplificar o sentido de pertença ao grupo e o caráter nobre desta pertença. Ao mesmo tempo, indicam a dificuldade de ser um Delta e o renascimento pessoal provocado pela pertença, visto quase como um rito de passagem (Van Gennep 1978) e, sempre, dentro de um espaço de liminaridade (Turner 1990; Douglas 1976) onde a opção de se tornar um Delta estabelece para o sujeito um antes e um depois dela e situa esse mesmo sujeito em um lugar no mundo através e a partir dessa integração e reconhecimento:

Galinha D'água é um cara da porra. Eu me miro nele toda vez que acho que vou fraquejar e não conseguir os meus intentos. Uns caras quiseram botar ele pra correr de uma parada, ameaçaram ele, mas ele conseguiu dobrar os caras e ainda trouxe depois três deles pra juntar-se aos Deltas... A gente não quis logo aceitá-los, mas ele foi demonstrando pra cada um que confiança se adquire dando e fazendo os outros acreditarem que a gente confia neles e que eles também podem vir a fazer parte se confiar[em] em nós e, sobretudo, neles mesmos. ${ }^{17}$

Outro jovem ${ }^{18}$ relata "a importância de ter-me tornado um Delta". Fala da falta de sentido de sua vida até o momento em que descobriu os Deltas, se aproximou e tornou-se um deles, e da importância de Colchão nessa trajetória "um cara" que considera ser "do caralho" -, quanto à demonstração do que se deve ser para se atingir a plenitude, quando alguém torna-se e é um Delta:

17 Entrevista feita em fevereiro de 2002, com um rapaz de 26 anos, Delta desde os 20. Solteiro, mora com os pais, não trabalha e cursa o quarto período de um curso na área de ciências humanas na Universidade Federal da Paraíba, campus I. Através deste rapaz o pesquisador tomou conhecimento sobre os Deltas e pôde se aproximar e fazer os primeiros contatos com o grupo.

18 Entrevista realizada no mês de maio de 2002, com um rapaz de 23 anos, Delta há quase um ano. Separado, não estuda, trabalha como mecânico em uma oficina do bairro em que mora e divide uma pequena casa com mais dois amigos, ambos Deltas. 
Tinha acabado de me separar de G., com quem tive um casamento de quatro anos. Foi a mulher que mais amei até hoje, ela era mais velha e me encantou e eu vivia de quatro, de cinco por ela. Larguei tudo, os estudos, a família, os amigos pra ficar com ela e depois deu no que deu, ela achou um homem mais velho, com posses, e me mandou passear... Eu tava numa merda só, só chorava e bebia, dormia pelas ruas, uma merda... Tava até pra ser demitido quando Colchão se aproximou e tentou me levar na conversa, a falar comigo, me levou pra casa dele e foi me fazendo entender que a vida era outra coisa. No início resisti muito, achei que o cara era veado ${ }^{19}$ e coisa e tal, mas depois vi que o cara só queria ajudar e fui me entregando por inteiro e fui entendendo que a vida pode ser legal, e fui conhecendo um ali outro acolá, os Deltas, e fui começando a fazer parte, ainda sem saber, e, quando vi, já era um Delta.

Os dois depoimentos falam do caráter nobre da pertença, falam dos riscos pessoais por que passa um Delta na busca de ajudar o outro e tentar convertê-lo ou possibilitar que se torne confiável e confiante no processo de descoberta da vida e na ação posterior de renovação identitária. Falam também do "dever ser", visualizado nas ações exemplares que passam a ser referências do agir individual e grupal dos Deltas. Referem atitudes afirmativas que enobrecem e honram o sentimento de pertencer ao corpo Delta, mas que, por trás, parecem constituir uma fonte de tensão constante no interior das relações do grupo e para o sujeito na sua prática cotidiana. De um lado, por exigirem um disciplinamento pessoal, mais acurado ainda nas ações Delta. Do outro lado, por promoverem uma disputa muda, travestida de admiração, entre os membros em relação. A disputa é sentida no poder acumulado pelas diversas pontuações das ações-modelo, assim consideradas pelo grupo ou advogadas por membros ou facções internas. Essas facções são invisíveis, é verdade, subliminares, negadas em discurso, mas concretizadas na lealdade de uns face a outros ou na prática de favores e proteção. Membros específicos, assim, parecem adquirir um poder sobre os outros por sua abnegação ou pelo conjunto de ações-modelo que praticam sobre os demais membros, quebrando um conceito de igualdade que paira entre os Deltas e encaminhando-os para uma conceituação confusa ou ambivalente e sempre negada da hierarquia no interior do próprio grupo.

A hierarquia é movida pela noção do valor das ações-modelo praticadas, que distingue um membro de outro e, ao mesmo tempo, indutora da disputa entre lideranças oficiosas sobre o destino e as conseqüências do ser Delta, isto é, de pertencer ao grupo e corresponder ao complexo moral e valorativo imposto ou 
configurado no momento da opção. ${ }^{20} \mathrm{~A}$ disputa se estende por toda a comunidade Delta, através das afiliações, espontâneas ou não, dos diversos membros às lideranças despontadas.

Não que esta disputa seja um elemento valorizado no grupo; pelo contrário, o ideal de igualdade dos membros e a ressignificação simbólica da confiança no conjunto e em cada um como iguais é a característica de todos os depoimentos. De outra parte, porém, a presença de ações-modelo quebra a esfera de igualdade e introduz uma desigualdade entre os membros, que passam a situar-se entre um "dever ser" como instância coletiva e uma diversidade de sentimentos sobre as metas a atingir pessoalmente no espaço grupal, movimentado por pontuações e modelos de ações vinculados a pessoas específicas, membro $a$ ou $b$, e que de uma forma ou de outra despontam como lideranças em jogo na prática do grupo. As lideranças são trabalhadas, inclusive, sobre o grau de proximidade ou de afinidade entre membros individuais, o que repercute, também, nas relações destes mesmos sujeitos entre si.

Um complexo jogo de situações não declaradas parece envolver os membros como um todo e cada membro individualmente nas formas comportamentais e modelos de ação seguidos por cada um ou a serem observados pelo grupo. Isto pôde ser sentido nas conversas individuais tidas com diversos informantes. As aproximações de alguns sujeitos hierarquicamente em situação de liderança pelos pontos acumulados em ações-modelo, a defesa das ações desse(s) sujeito(s), a busca de segui-los ou o almejar acompanhá-los como exemplos do que é ser um Delta, tudo isso parece provocar uma querela silenciosa com outras práticas e ações exemplares e seus executores e seguidores. Mas essa querela é prontamente negada ou, quando o entrevistador a percebe e chama a atenção para ela, procuram justificar que não é bem assim. Isso aconteceu no depoimento de uma moça que relatava a sua paixão por um membro específico do grupo e o comparou a outro membro. Quanto notada a comparação pelo entrevistador, tentou modificar o discurso e demonstrar que não era bem assim, que não existia disputa e não existe melhor entre os Deltas, pois todos são iguais e confiáveis:

a razão de ser Delta me foi apresentada sobremaneira por Cabelinho numa vez que ele agiu sobre o preconceito de uma parte do grupo - as insinuações de que uma determinada menina era de programa - e os convenceu de que, mesmo se ela fosse, o grupo deveria agir no sentido de dar a ela apoio moral, de fazer com que eles [fossem] confiáveis para ela e conseguir a confiança

20 Para a questão das lideranças entre os Deltas, em uma relação que no discurso não é hierárquica, ver o conceito de "empreendedor moral" usado por Howard Becker no seu famoso livro Outsiders (1997). Friso, contudo, que o conceito de Becker diz respeito apenas a uma das facetas da liderança oficiosa, difusa e negada em discurso, exercida entre os Deltas. 
dela nela mesma. Isso me comoveu e me comove até hoje. Não que ele seja melhor ou pior, ele é igual, mas eu me baseio aqui e lá pelas ponderações dele para elaborar as minhas próprias e basear as minhas ações. Acho ele um cara arretado e digno do que eu acho que é ser um Delta. ${ }^{21}$

A disputa pode também levar um membro individual a se sentir inseguro quanto a alcançar os limites das ações-modelo, ou mesmo, ao contrário, estimular a concorrência entre os membros, ao buscarem superar essas ações com novas ações gloriosas que possam colocá-los em situação de destaque no grupo. Em um e no outro caso, disputas e tensões são provocadas tanto no sentido da busca de um autocontrole e segurança nas ações, quanto através de um sentimento de inferioridade ou ressentimento por não se saber capaz de atingir as metas ou não ser reconhecido no seu esforço para tal.

Claro que tudo isto é disfarçado em um amálgama de discursos dissimuladores, onde os elementos de igualdade e confiabilidade são ressaltados para averiguação das ações na totalidade grupal, o que escamoteia o jogo de tensões entre as partes em relação e as disputas individuais ou coletivas sobre o comportamento necessário para se portar como um Delta ou erigir ações-modelo que se tornem códigos disciplinares ou metas a serem atingidas pela comunidade dos Deltas.

\section{MEDOS E SEGREDOS}

O receio de não se portar como um Delta dissimula as práticas discursivas abertas que elejam a disputa e as formas desiguais de inserção no grupo no exercício e pontuação de ações-modelo. Essa dissimulação, por outro lado, não significa um compromisso pelo consenso. Pelo contrário, ao se colocar de forma silenciosa e insidiosa, parece aumentar os elementos próprios da rede de disputas e hierarquias no grupo e ampliar as configurações de poder interno entre os membros, o que os leva, como um todo, a recearem assumir uma atitude clara perante os outros sobre os significados de cada ação, sobre os compromissos de uns para com os outros, sobre as vinculações ou ações vinculares internas que possibilitam a emergência de grupos informais entre eles, e sobre as inseguranças quanto às metas a serem atingidas e ao próprio significado intrínseco do que é ser um Delta, para cada um. ${ }^{22}$

21 Depoimento de jovem de 20 anos que concedeu a primeira entrevista em abril de 2002. Solteira, estuda o terceiro ano do ensino médio em uma escola municipal do bairro em que mora. Mora com os pais e namora um dos membros dos Deltas; está se preparando para prestar vestibular.

22 Não cabe no escopo deste trabalho, por falta de espaço, uma comparação do movimento Delta com outros movimentos estudados no Brasil e no mundo ocidental. O leitor, nesse sentido, é remetido para o estudo clássico de Whyte (2005) sobre movimentos urbanos juvenis. Ver, também, Hall e Jefferson (1993) sobre movimentos jovens na Inglaterra no pós-guerra e o artigo de [continua] 
Isso parece criar um labirinto por onde medram alianças e disputas silenciosas, desejos e insatisfações caladas e medo de, ao ser percebido, se perder o estatuto de Delta ou, ainda, medo da descoberta de que a autoconfiança que um Delta possui ou deve possuir é apenas uma intenção simbólica que movimenta o indivíduo para fora e não necessariamente para dentro do grupo, ${ }^{23} \mathrm{e}$ de que no interior deste o que prevalece é a insegurança sobre a capacidade de cada um autocontrolar-se e proporcionar ao outro segurança, e a afirmação de afinidades que corroboram alianças e dissensões, mesmo que dissimuladas, entre os membros do grupo.

O ocultar a face goffmaniano, assim, parece ser uma das armas de dissimulação que ajudam a manter a união do grupo, em seu complexo moral mais amplo e no sentimento coletivo e individual de pertencer ou de ser um Delta. Goffman (1980), em seu estudo sobre a elaboração da face, discute o problema da interação social como um conjunto de elementos capazes de dar corpo a uma relação dada. Fala do sentido de elaborar a face como busca de se adequar aos outros relacionais: um padrão de atos verbais e não verbais, segundo ele, através dos quais um sujeito enfrenta o outro social, expressa sua situação na relação e faz uma avaliação dos participantes e, especialmente, de si mesmo (1980: 76).

A elaboração da face, deste modo, para Goffman, faz parte da cultura da interação social e está presente em toda e qualquer forma de sociabilidade. As formas de organização da face em interação mudam, contudo, de cultura a cultura, por seguirem ou acompanharem todo um conjunto de valores, normas e regras estipuladas socialmente e ao alcance dos indivíduos em interação.

Mary Bucholtz (2002) sobre juventude e práticas culturais, além do ótimo artigo de Vigil (2003) sobre violência urbana e gangs de rua, indicado por um dos pareceristas a quem o autor agradece a indicação, e que traz uma boa bibliografia sobre movimentos juvenis nos Estados Unidos. Diferentemente destes últimos, os Deltas se constituem em um movimento afirmativo do jovem morador da periferia da cidade de João Pessoa, contrário à violência das ruas, às drogas e em busca da integração do jovem na sociedade mais ampla, através da autoconfiança adquirida como membro Delta. Para uma visão do caso brasileiro, se dirige o leitor para a interessante coletânea organizada por Hermano Vianna (1997).

23 O status formador de um Delta identifica e dá identidade a cada membro individual. Através da qualificação de ser um Delta se adquire uma postura e um olhar para o mundo ao redor. O sentimento de pertença cria ou estabelece canais de semelhança e identificação grupal e com outros Deltas, ao mesmo tempo em que estabelece a diferença individual necessária para o trato e para as relações com os outros fora do mundo Delta. Magnani (1998), falando sobre a cultura na rua, fala sobre a categoria "pertencer" como uma disposição individual e grupal de uma referência concreta pela qual alguém pode ser reconhecido enquanto diferente. A pertença significaria, assim, "um espaço de mediação cujos símbolos, normas e vivências permitem reconhecer as pessoas diferenciando-as, o que termina por atribuir-lhes uma identidade que pouco tem a ver com a produzida pela interpelação da sociedade mais ampla e suas instituições" (1998: 117). Este trabalho, por outro lado, está mais preocupado com as tensões no interior de um grupo social, no caso os Deltas, entre a busca de identificação e identidade individual e grupal e as disputas invisíveis em torno do ser Delta. 
Cada indivíduo tem dentro de si as diversas performances possíveis do que se espera dele e do que ele espera do outro em cada situação de inter-relação, e as faces dos sujeitos relacionais vão se moldando, ou parecem fazê-lo, de acordo com as exigências da situação social em que está incluso. Goffman afirma que a discrição é o elemento ritual básico em uma convivência inter-relacional na qual o indivíduo envolvido conhece bem os outros sujeitos da interação, sabendo que temas devem ser abordados ou quais devem ser silenciados (Goffman 1967), havendo uma gama de temáticas, entre as que é possível abordar e as silenciadas, que podem ser levantadas e discutidas sem haver grande problema entre as partes.

Neste ritual, de um lado, o "salvar a face" ${ }^{24}$ e o "proteger a face" do outro ${ }^{25}$ são atitudes que medeiam uma interação entre possíveis comparsas de uma mesma lógica grupal buscando, em um ou no outro modo, uma convivência pacífica e conforme às exigências do grupo ao qual pertencem. Por outro lado, nesta busca de uma convivência pacífica parece existir, simultaneamente, um receio de se encontrar fora do lugar, se expondo ou expondo outros a processos de humilhação.

O medo da humilhação remete o sujeito a uma situação de ocultação da face. O indivíduo esconde-se como forma de não se expor, ou como modo de dissimular o sentimento de estar fora do lugar que ocupou, o que o leva a buscar, através da atitude de indiferença, sair da cena em que se viu envolvido sem prejudicar a sua imagem, ou prejudicando-a o menos possível, nem a do outro. ${ }^{26}$ Em situações deste tipo é comum, entre os Deltas, ocultar-se nas entrelinhas da fala de outros membros do grupo em que se sintam apoiados ou a quem apóiam. Em cenários considerados perigosos para a exposição pessoal ou onde não se sintam seguros, usam membros que consideram terem maior poder de persuasão no interior do grupo para a intermediação de interações consideradas por eles mais delicadas e comprometedoras.

É o que apresenta, embora de forma não inteiramente explícita, o depoimento de uma jovem que se encontra há menos de um ano entre os Deltas:

24 É o processo onde a pessoa sustenta para os outros a impressão de não ter perdido a face (Goffman 1980: 80).

25 É uma ação que visa salvar a face do outro, buscando ajudá-lo e ajudar a si próprio. Em uma ação de proteção da face de um outro, para Goffman, parece coexistir uma situação onde o terceiro envolvido corre o risco de perder a própria face se não o socorrer (Goffman 1980: 86). No caso dos Deltas, esta situação parece evitar, assim, o descrédito pessoal, junto do grupo, daquele que moveu uma ação protetora, levando-o, ainda, a ganhar um provável aliado importante para suas ações no próprio grupo.

26 Isto em relação ao outro do mesmo grupo. Em presença de uma situação estranha ou em presença de estranhos, o processo de discrição e o medo de se sentir humilhado e usado parecem aumentar, fazendo o sujeito em relação ocultar a face ou restringir-se apenas ao processo ritual interativo de fórmulas e instâncias por ele bem conhecidas, onde se possa sentir seguro (Goffman 1980: 85). 
[...] eu fui tomada pelo encantamento das coisas Delta desde o dia em que Mingau me pôs a par do grupo e que eu fui me aproximando e coisa e tal e me encontrei fazendo parte. Eu tenho muito medo de errar, de não ser inteiramente fiel ao grupo, embora tente imensamente. Vivo em constante sobressalto toda vez que tenho que participar de um encontro com outros membros que eu não sou, vamos dizer assim, chegada. Mesmo entre os meus, isso é, entre as pessoas com quem ando mais e tenho mais afinidades, eu me balanço todinha toda vez que tenho que falar ou dizer algo. Só digo quando não tem jeito, e mesmo assim me cagando pra não dizer bobagem ou magoar ninguém. Ainda bem que tem o Pensão que não deixa eu falar bobagem. Com ele eu me abro nessas coisas e ele diz que é assim mesmo e que ele não deixará que eu escorregue na maionese... Ele é um cara legal. Confio nele pra caraca e posso dizer que mais nele do que em mim, e às vezes, Deus me perdoe, ele é o meu grupo. É por ele e nele que me dedico ao todo com um amor maior do que minha pessoa tão pequena. Acho que com o tempo eu circularei melhor, mas por enquanto é bom demais. É bom ter gente que confia na gente e a gente pode confiar em troca. Pensão, Mingau e uma turma enorme me abrem o jogo e me protegem de mim mesma e das agressões das besteiras que faço e os outros vez por outra tentam me reprimir... ${ }^{27}$

Os intermediadores, em uma situação nunca explícita de angariar mais poder junto ao grupo maior, servem como figuras protetoras e se prontificam a conduzir determinadas interações, ou melhor, situar um ou outro membro em situação de vergonha ou insegurança no grupo, em troca de uma maior lealdade à sua pessoa. Estabelece-se, deste modo, uma situação estranha de estratificação social dentro de um discurso de iguais. Isso introduz uma ambigüidade nas relações sociais internas e parece originar tipos de participação não legitimada no discurso oficial do grupo, mas que, ao mesmo tempo, o fortalecem e o legitimam, por abrirem espaços de atuação para uma gama maior de situações individuais em relação ao padrão de confiança e confiabilidade do grupo como um todo.

A questão da segurança, apesar de ser um assunto que diz respeito a todos os membros do grupo, é repassada entre os Deltas por um sistema complicado de proteções e intermediações. Os protetores e intermediadores executam o papel, não declarado, de dar segurança aos mais inseguros, permitindo a sua participação no grupo através deles e, ao mesmo tempo, permitindo uma maior segurança àquele como um todo, através da palavra de confiabilidade sobre seus protegidos e de confiança nos ideais dos Deltas.

27 Entrevista realizada em maio de 2002, com uma jovem de 20 anos de idade, com o ensino médio recém-concluído e que se prepara para fazer vestibular para um curso na área das ciências da natureza. Solteira, tímida, mora com os pais e trabalha em um consultório médico como recepcionista. 
O processo é, sem dúvida, confuso e sujeito a dissensões, medos e receios. Em um ambiente de iguais situam-se várias facções movimentadas por protetores e protegidos. Estas facções, por seu turno, também são entrecortadas por esquemas de intermediação entre os diversos subsetores que parecem se formar entre o líder e o mais inseguro ou recém-entrado no grupo dos Deltas. Cada um dos níveis de intermediação submete o outro mais frágil a um conjunto de lealdades e confiança em si, ao intermediar entre aquele e os outros níveis hierárquicos de configuração do poder interno formado, conhecido, mas ocultado e deslegitimado quando por ele se pergunta explicitamente.

Foi o que aconteceu quando foi perguntado a um dos líderes, ou um dos membros em situação de liderança, indicado como tal por vários outros, o que o fazia ser líder. Ele olhou sério o entrevistador e respondeu:

[...] aqui não há liderança nem líderes. Todos somos iguais. A confiança é estabelecida para todos, todos gozam dela e participam do mesmo modo na construção Delta da pessoa e do mundo. Somos iguais e isso é que nos faz importantes e nos dá dignidade de enfrentar o mundo fora da nossa comunidade. $^{28}$

Com a insistência de vários outros membros entrevistados na indicação desse jovem como um líder Delta, afirmou:

Não é que eu seja líder. Como já disse, aqui não há líder, nem liderança, nem liderados, aqui somos todos um só com a mesma repercussão e vivência na comunidade. Mas o que os camaradas quiseram dizer, talvez tenha sido que eu não deixo outros aqui dentro pisar nos nossos, eu defendo cada Delta como se fosse eu mesmo. Aí essa história de líder... é não, é brincadeira da turma... mas tenho certeza de que o que eu faço é pelo espírito Delta, e sei que cada um deles, cada Delta, faria o mesmo por mim.

O trânsito entre os diversos subsetores formados, como uma espécie de níveis hierárquicos de intermediação, parece, assim, configurar-se como um exercício de tensão e medo cotidiano de explicitação, e resulta em um aumento da discrição. Cada ato é medido, premeditado e avaliado por quem o executou e por todos os demais membros do grupo. Parece haver uma cobrança exacerbada sobre cada processo desencadeado pelo ato de alguém ou de um grupo e ela serve, de forma simultânea, para um melhor avivamento do grupo. Também dá margem para lutas surdas em torno das determinações, definidas pelo grupo ou movidas pela ação de um dos membros ou facções para o grupo como um todo.

28 Entrevista realizada em maio de 2002, com um rapaz de 26 anos que cursa o penúltimo período de um curso superior na UFPB. É considerado um dos fundadores dos Deltas. Solteiro, mora com os pais, não trabalha e dedica todo o tempo disponível ao trabalho com o grupo Delta. 
Simmel (1964) discute o significado do segredo na construção da individualidade e da sociabilidade. Apresenta uma relação sempre tensa entre os indivíduos e considera a discrição um elemento importante na configuração de uma formação social. Os indivíduos em relação que compõem uma forma social asseguraram a posse de um segredo comum, o que significa a partilha e a comunhão dos bens simbólicos do grupo. Após a composição do grupo, as interações envolvidas estendem-se por laços que visam, de um lado, proteger o segredo do outro a ele confiado, ou o segredo do grupo confiado a ambos, e, principalmente, de outro lado, manter a distância perante tudo o que o outro não revela explícita ou expressivamente.

Ao discutir o conceito de segredo e sua importância para a compreensão e formulação do social, Simmel irá tocar o tempo inteiro na tecla da insegurança e do medo que provoca a ação, na configuração e na remontagem dos projetos socialmente dispostos pela ação social de indivíduos e grupos. Antes de indicar um aspecto negativo para a ação social, a insegurança provoca em si a positividade da ação social e a especificidade desta ação como criadora de significados e suas possibilidades infinitas de se reproduzirem em novos formatos sociais e de individualidades.

Simmel coloca o segredo e a insegurança do outro relacional como momentos do instituinte social, e como fundamento da constituição da sociabilidade e do estabelecimento singular do diferencial que assemelha indivíduos, enquanto projeto, e os torna pessoas ou grupos em ação comum, ao mesmo tempo em que os assenta em um patamar de insegurança quanto ao quantum desta semelhança diferencial. Até que ponto um, o semelhante, detém a igualdade proporcionada pela posse do segredo do outro? O que provoca e como se institucionalizam os germens de hierarquização e administração das diferenças entre indivíduos ou grupos colocados em uma mesma posição ou de posse de um mesmo segredo?

O segredo pressupõe, assim, o tempo todo, o medo da traição. Indica a forma de revelar ao outro a intimidade e singularidade de uma comunidade (de afeto, de interesses), como modo de desfazer esta própria comunidade pelo desmascaramento daquilo que simbolicamente diz sobre a sua especificidade e unicidade frente às demais.

A possibilidade de traição, porém, em vez de anestesiar apenas, parece provocar a centralização e busca de eficácia do controle dos membros internos de uma comunidade de segredo na guarda e manutenção do mesmo. É o que parece informar um entrevistado:

Não que você vá negar ao outro a confiança necessária para torná-lo um membro nosso. Não mesmo. Mas, vez por outra, passa na minha cabeça, e acho que na cabeça de muitos, se não de todos, essa coisa de suspeitar. A gente suspeita o tempo todo, pode-se dizer. Eu suspeito de 
mim, primeiro, e aí vejo os outros como iguais a mim e sujeitos ao mesmo modo mole de ir adiante. Aí finco ainda mais em mim mesmo a idéia de que não posso cair, tenho que me superar, me superar, e aí vou nos outros de cara cobrando comportamento, verificando cada passo que pode ser em falso, e aplaudindo os passos legais. E aí, acho que a gente vai indo em frente, buscando mais confiança e confiando, mas sempre com um pé um pouco para trás... Não é que a gente desconfie o tempo todo não, de jeito nenhum, mas é a forma de o grupo se aprimorar, se disciplinar, mais e mais. ${ }^{29}$

Deste modo, e ao mesmo tempo, para ganhar o sentido da própria eficácia do segredo entre os comuns, o controle parece se fazer ou se exercer sob uma possibilidade de traição.

É a traição, em termos últimos, que assegura em boa medida, junto com as práticas ritualísticas de revisão e revisita ao segredo que irmana os membros de um grupo específico, a produção e reprodução deste segredo entre os membros, pela possibilidade da vigilância sobre a sua realização prática, real ou possível. É o medo que, neste caso, parece mover o próprio exercício da semelhança ou a busca de novas formas discursivas no interior ou no exterior de uma comunidade específica.

Do mesmo modo que a revelação do segredo permite a traição, ela leva também à eficácia e permanência do segredo em si mesmo, pela possibilidade de ampliação a novos membros. Contudo, aos novos membros propostos através da revelação se instaura uma prática relativa à confirmação da sua fidelidade ao segredo revelado e a diversas inserções práticas na vida cotidiana do grupo, como informa um entrevistado de 18 anos:

Faço parte dos Deltas há seis meses, e desde que entrei é tudo uma coisa demais para mim. Eu já não sou, posso dizer com tranqüilidade, o cara que era antes, perdido na vida, jogado nas coisas, não, eu agora sou outro, tenho um caminho pra trilhar. Mas não sei ainda se posso me considerar um Delta verdadeiro, ainda. Não sei, não. O montante de coisas que faz ser um Delta me faz às vezes enxergar para a distância que se situa [entre mim e o] que eu deverei chegar a ser. E me esforço, me esforço muito, mas vou com cuidado... não quero ser pisado e nem pisar em ninguém. Aí entram umas amizades mais chegadas aqui dentro que vão me orientando, me dando passagem, me

29 Entrevista realizada em maio de 2002, com um rapaz de 29 anos, um dos fundadores dos Deltas (segundo ele), casado, com um filho de dois anos. Ele e a mulher são Deltas, se conheceram no grupo, se gostaram e casaram. Ambos possuem uma pequena mercearia que abre de domingo a domingo e que serve como um dos pontos de encontro dos membros do grupo. 
fazendo clarear situações e puxando minhas orelhas na intimidade quando eu desando a desandar... ${ }^{30}$

Como pode ser visto no depoimento acima, apesar da revelação e do nascimento de um novo ser, agora Delta, a insegurança parece ser a companheira mais freqüente desta nova conformação, junto, claro, com o esforço desmesurado de autocontrole e de organização interna para o aprendizado. Isso leva o indivíduo a procurar proteção, ou a propor proteção a outro, apresentando-se este jogo como um elemento singular de sustentação da lealdade e da confiabilidade disposta nos outros, para os outros e pelos outros, e da não recaída em ações e projetos anteriores de onde adveio e pelos quais ainda não se sente inteiramente seguro.

A revelação ofertada ao novo membro, individual ou grupal, abre, assim, uma possibilidade de inserção ritual e simbólica na prática comum da comunidade dos Deltas. Leva, ao mesmo tempo, a uma reconfiguração deste sujeito face às estratégias do seu passado, a ser revisto e revisitado através da nova revelação, o que satisfaz e modifica o plano de vida individual e grupal, socialmente dado. Leva também, de um lado, a inseguranças próprias do rompimento com a velha ordem e à procura da manutenção dos novos valores, aderindo o sujeito a vinculações não legítimas de proteção e ocultação da face pela intermediação de outro membro considerado mais eficaz, configurando-se o medo como prática ritual a ser vencida, ou como um teste de confirmação face à revelação de que foi sujeito e significado.

Nos dois casos está se tomando como possibilidade de ação social as configurações relacionais postas em andamento por projetos específicos de indivíduos ou grupos em jogo. Se esses projetos, por um lado, se estabelecem sob um patamar de semelhança, abrigam um forte respaldo de desconhecimento para o outro da relação, o que torna a ação social um jogo de união sob determinados argumentos, sempre visualizado como perigoso e suspeito, por não se ter a segurança completa na administração do outro. Assim, o outro é sempre uma fonte de medo a ser controlada ou a ser reconfigurada e transposta para uma nova situação de semelhança possível, sempre trabalhada, sempre buscada como um ideal de chegada. Ou talvez de partida, ou de recomeço.

\section{CONCLUSÃO}

Este artigo, enfim, compreendeu o sentido de pertença e sua relação com os códigos da confiança e lealdade, conceitos aqui entendidos sob a ótica do

30 Entrevista concedida em abril de 2002 por um rapaz tímido e sério, estudante da oitava série noturna do ensino fundamental, de uma escola pública estadual do bairro onde mora. Solteiro, mora com dois irmãos, não conheceu os pais, falecidos. Trabalha como office boy para uma firma de advogados no centro da cidade de João Pessoa. 
medo da traição ou da insegurança individual quanto a não conseguir alcançar os ideais do grupo estudado. O seu objetivo foi o de perceber o processo organizativo interno do grupo e as redes vinculares que dão sustentáculo e base de apoio à sociabilidade grupal.

A confiança e a confiabilidade foram os elementos categoriais trabalhados para a compreensão do significado da pertença ao grupo. O sentido e a vivência da noção de confiança foram vistos como um aspecto da constituição ambígua do medo do outro e da sua ultrapassagem. Neste lugar, os laços afetivos são intensos e comuns, assemelhando cada membro ao outro, ao mesmo tempo em que ele parece assegurar um espaço de diferenciação individual das pessoas envolvidas em relação à sociedade em geral.

O sentimento de pertencer foi uma categoria fundamental para a compreensão dos laços de confiança e os sentidos de confiabilidade que transformam um indivíduo em Delta e o fazem vivenciar o sentido de comunhão de interesse e vontade como grupo, de onde parece advir um sentido de similitude que o iguala aos demais membros, tornando-os uma comunidade. Ser leal e obter lealdade em troca são os resultados esperados deste sentimento de pertença e o fundamento da proteção.

Esse sentimento remete, por sua vez, aos espaços construídos de confiança e confiabilidade no, para e pelo grupo. A revelação de saber-se confiável e poder confiar parecem permitir a cada membro individual e ao grupo em geral a certeza de formarem uma comunidade de valores morais, uma comunidade moral em que a segurança e a lealdade criam as condições de apropriação e manutenção de uma prática social e pessoal, ao mesmo tempo em que assombram o grupo e cada membro particular sob o perigo da traição.

A segurança foi estudada pelo seu aparecimento no grupo como associada à confiança. Estar em segurança é se encontrar convicto, seguro ou certo da resposta do outro. O confiar no outro e nas próprias ações parece evocar, deste modo, um sentido de troca ou uma espécie de sinônimo da categoria lealdade. O reforço da necessidade de o indivíduo ser leal para com os outros implica, do mesmo modo, o anseio de que os outros sejam leais para com ele. Se essa necessidade de lealdade cria os liames da segurança, provoca também a incerteza nela contraída para a comunidade moral e para as relações entre Deltas, e a traição passa ser o elemento que movimenta o grupo e cada membro individual.

Um ato de reciprocidade identifica o semelhante pela familiaridade confiada aos membros do coletivo e, ao mesmo tempo, os diferencia como sujeitos no mundo nas trocas necessárias com outros grupos e a sociedade em geral. Os conceitos de fidelidade e confiança, assim, no grupo Delta, parecem permitir a fundação de uma rede complexa de reciprocidade que assegura a segurança e a conformidade individual através da emoção vergonha, encarada, no e pelo grupo, como constitutiva do caráter individual e como sedimento da moral 
grupal. O caráter individual é sempre coadunado com os dispositivos morais do grupo.

O orgulho de ser um membro Delta parece ser orientado, portanto, por um controle social estabelecido pelo grupo e um controle individual sobre o próprio sujeito da ação e cada ação pessoal, seja ela dirigida aos membros individuais ou ao grupo como um todo. Esta ação disciplinar seguida pelo indivíduo relacional com relação a si mesmo e exigida para todos no grupo parece equivaler, entre os Deltas, a uma forma de reconhecimento individual no grupo e de auto-reconhecimento como pessoa singular a partir do grupo.

O controle social grupal e o autocontrole parecem sugerir um tipo de racionalidade de ações em que a emoção é regrada através do sentido a ela atribuído pela pessoa que a pratica e por aqueles que a ela reagem. $\mathrm{O}$ reconhecimento do outro se transforma, portanto, em uma relação delicada porque sujeita a interpretações e expetativas várias da ação ou da intenção por parte do outro da relação ou do próprio sujeito da ação. Proporciona, ao mesmo tempo, um aumento da autodisciplina e um aumento dos mecanismos de segurança individual e grupal, como forma de defesa daquele que impulsiona a ação e do outro, alvo da ação. Essa relação é sempre tensa, porque movimentada por sentimentos de não correspondência entre as suas ações e o que é buscado e erigido pelo grupo, visto como uma espécie de ação ideal ou modelar.

O receio de errar ou não ser bem interpretado pelo outro da relação provoca um movimento de aprimoramento das ações e um crescimento do exercício crítico sobre o outro e sobre si mesmo. Uma espécie de disputa silenciosa parece então ocorrer. Cada membro busca se guiar por essas ações-modelo, que, por sua vez, se tornam motivo de orgulho para o grupo em geral e são contadas e exteriorizadas por todos como afirmação do ser Delta. Idéias de sacrifício pessoal, de enobrecimento do outro, de autodisciplina e rigor disciplinar são evocadas, nos vários depoimentos recolhidos, como querendo indicar o sentido de pertença ao grupo e o caráter nobre desta pertença.

A exigência de um disciplinamento pessoal e a exigência disciplinar mais acurada nas ações Delta parecem então ganhar definição e são sentidas através de um mecanismo complicado que estabelece diversas pontuações às ações-modelo e permitem uma acumulação de poder por parte de membros individuais ou facções internas. Membros específicos parecem adquirir poder sobre os outros pelo conjunto de ações-modelo que praticam, quebrando o conceito de igualdade que paira entre os Deltas e levando o grupo a uma conceituação ambivalente de hierarquia no seu interior.

A hierarquia é movida pela noção do valor conquistado em cada ação-modelo praticada, que distingue um membro de outro e, ao mesmo tempo, parece provocar uma disputa entre lideranças oficiosas sobre o caráter de pertencer e o complexo moral e valorativo imposto ou configurado no momento da opção Delta. Essa disputa parece se estender por toda a comunidade Delta. 
As disputas e as tensões parecem ser provocadas, assim, tanto pela busca de um autocontrole e segurança nas ações quanto por um sentimento de inferioridade ou ressentimento por o indivíduo não se saber capaz de atingir as metas ou não ser reconhecido no seu esforço para tal.

O receio de não saber se portar leva à dissimulação das práticas discursivas que elejam a disputa e formas desiguais de inserção no grupo no exercício e pontuação de ações-modelos. Essa dissimulação não significa, contudo, um compromisso pelo consenso; ao contrário, ao se colocar de forma silenciosa e insidiosa, parece aumentar os elementos próprios da rede de disputas e hierarquias no grupo e ampliar as configurações de poder interno entre os membros.

A ocultação da face torna-se, deste modo, uma arma de dissimulação que ajuda a manter a união do grupo, em seu complexo moral mais amplo e no sentimento coletivo e individual de pertença. $\mathrm{O}$ medo da humilhação de não ser reconhecido como um Delta parece remeter o sujeito a uma situação de dissimulação e ocultação da face. Em situações deste tipo é comum, entre os Deltas, o indivíduo ocultar-se na fala de outros membros em que se sinta apoiado ou a quem apóia. Isso parece estabelecer uma ambigüidade nas relações internas e originar tipos de participação não legitimada no discurso oficial do grupo, o que, de uma forma ambígua e ambivalente, parece fortalecer e legitimar o grupo como um todo, por abrir espaços de atuação para um amplo leque de situações individuais em relação ao padrão de confiança e confiabilidade do grupo como um todo.

O conceito de segurança entre os Deltas, portanto, é realizado através de um complicado sistema de proteções e intermediações. Cada ato é medido, premeditado e avaliado por quem o executou e por todos os demais membros do grupo. Uma cobrança exacerbada sobre cada processo desencadeado pelo ato de alguém ou de um grupo parece acontecer e serve, de forma simultânea, para um melhor avivamento do grupo, como também dá margem para lutas surdas pelas determinações do grupo ou movidas pela ação de um dos membros ou facções para o grupo como um todo.

A incerteza e o medo que provocam a ação parecem estar presentes na configuração complexa da segurança, como acepção de confiança, entre os Deltas. O controle social e a confiabilidade são exercidos na prática cotidiana do grupo sob a possibilidade de traição, ao mesmo tempo em que fornecem o sentido da própria eficácia do segredo entre os comuns.

É o medo da traição que parece assegurar a produção e reprodução do segredo e da semelhança entre os membros. As práticas ritualísticas de revisão e revisita ao segredo que enobrece o grupo parecem só ser possíveis no grupo Delta pela vigilância permanente sobre a sua realização prática. É o medo que, neste caso, parece mover o próprio exercício da semelhança, ou a busca de novo desenho ético no grupo. 


\section{BIBLIOGRAFIA}

ABU-LUGHOD, Lila, e Catherine LUTZ (eds.), 1990, Language and the Politics of Emotion.

Nova Iorque, Cambridge University Press.

ARENDT, Hannah, 1974, Vies politiques. Paris, Gallimard.

— 1993, "Só permanece a língua materna”, em Hannah Arendt, A Dignidade da Política:

Ensaios e Conferências. Rio de Janeiro, Relume-Dumará, 123-177.

BECKER, Howard S., 1997, Outsiders: Studies in the Sociology of Deviance. Nova Iorque, The Free Press, 13. ${ }^{\mathrm{a}}$ ed.

BOURDIEU, Pierre, 1968, "El sentimiento de honor em la sociedad de Cabilia", em J.G.

Peristiany (org.), El Concepto del Honor en la Sociedad Mediterránea. Barcelona, Editorial

Labor, 175-224.

BUCHOLTZ, Mary, 2002, "Youth and cultural practice", Annual Review of Anthropology, 31: 525-552.

COElho, Maria Claudia, 2006, O Valor das Intenções: Dádiva, Emoção e Identidade. Rio de Janeiro, FGV Editora.

DOUGlaS, Mary, 1976, Pureza e Perigo. São Paulo, Perspectiva.

DUBAR, C., 1997, A Socialização: Construção das Identidades Sociais e Profissionais. Porto, Porto Editora.

—, 2000, La crise des identités. Paris, PUF.

DURKHEIM, Émile, 1996, As Formas Elementares da Vida Religiosa. São Paulo, Martins Fontes.

EKMAN, P., 1993, "Facial expression and emotion", American Psychologist, 48 (4): 384-392.

ELIAS, Norbert, 1990, O Processo Civilizador, vol. I. Rio de Janeiro, Zahar.

—, 1993, O Processo Civilizador, vol. II. Rio de Janeiro, Zahar.

FOUCAUlT, Michel, 1979, Microfísica do Poder. Rio de Janeiro, Graal.

GOFFMAN, Erving, 1967, Interaction Ritual: Essays on Face-to-Face Behavior. Nova Iorque, Anchor Books.

__, 1980, "A elaboração da face: uma análise dos elementos rituais na interação social", em S. A. Figueira (org.), Psicanálise e Ciências Sociais. Rio de Janeiro, Francisco Alves, 76-114.

—_, 1985, A Representação do Eu na Vida Cotidiana. Petrópolis, Vozes, 3. a ed.

HALL, Stuart, e Tony JEFFERSON, 1993, Resistance through Rituals: Youth Subcultures in Post-War Britain. Londres, Routledge.

HARKOT-DE-LA-TAILLE, Elizabeth, 1999, Ensaio Semiótico sobre a Vergonha. São Paulo, Humanitas.

HELlER, Agnes, 1983, Sobre os Instintos. Lisboa, Editorial Presença.

HOCHSCHILD, A. R., 1997, The Time Bind. Nova Iorque, The Metropolitan Books.

— 2003, The Commercialization of Intimate Life: Notes from Home and Work. Berkeley, University of California Press.

HOLLAN, Douglas, e J.C. WELLENKAMP, 1996, The Thread of Life: Toraja Reflections on the Life Cycle. Honolulu, University of Hawaii Press.

KOURY, Mauro Guilherme Pinheiro, 1998, "Fotografia e a questão da indiferença", em Mauro Guilherme Pinheiro Koury (org.), Imagem \& Ciências Sociais. João Pessoa, Editora Universitária, 67-86.

—, 2001, "Enraizamento, pertença e ação cultural”, Cronos, 2 (1): 131-137. 
KOURY, Mauro Guilherme Pinheiro, 2003, Sociologia da Emoção: O Brasil Urbano sob a Ótica do Luto. Petrópolis, Vozes.

— 2004 , Introdução à Sociologia das Emoções. João Pessoa, Manufatura/GREM.

—, 2006, O Vínculo Ritual: Um Estudo sobre Sociabilidade entre Jovens no Urbano Brasileiro Contemporâneo. João Pessoa, Editora Universitária.

—_, 2008, De Que João Pessoa Tem Medo? Uma Abordagem em Antropologia das Emoções. João Pessoa, Editora Universitária.

MAGNANI, José Guilherme Cantor, 1998, Festa no Pedaço: Cultura Popular e Lazer na Cidade. São Paulo, Hucitec.

PERISTIANY, J. G. (org.), 1968, El Concepto del Honor en la Sociedad Mediterrânea. Barcelona, Editorial Labor.

SCHEFF, Thomas J., 2001, "Três pioneiros na sociologia das emoções”, Política \& Trabalho, XVII (17): 115-127.

SCHWARZ, N., 2002, "Feelings as information: moods influence judgments and processing strategies”, em T. Gilovich, D. Griffin e D. Kahneman (eds.), Heuristics and Biases. Nova Iorque, Cambridge University Press.

SENNET, Richard, 2001, Autoridade. Rio de Janeiro, Record.

SIMMEL, Georg, 1964, "The secret and the secret society", em Kurt H. Wolf (ed.), The Sociology of Georg Simmel. Nova Iorque, The Free Press, 307-376.

—, 2005, "O estrangeiro", Revista Brasileira de Sociologia da Emoção, 4 (12): 350-357 (disponível em <http://www.cchla.ufpb.br/rbse/index.html>).

SOUZA, Marcos Alvito Pereira de, 2000, "A honra de Acari”, em G. Velho e M. Alvito (orgs.),

Cidade e Violência. Rio de Janeiro, Editora da UERJ/Editora da FGV, 148-165, 2. ${ }^{\text {a }}$ ed.

TURNER, Victor, 1990, Le phénomène rituel: structure et contre-structure. Paris, PUF.

VAN GENNEP, Arnold, 1978, Ritos de Passagem: Um Estudo Sistemático. Petrópolis, Vozes.

VIANNA, Hermano (org.), 1997, Galeras Cariocas: Territórios de Conflitos e Encontros Culturais.

Rio de Janeiro, Editora da UFRJ.

VIGIL, James Diego, 2003, "Urban violence and street gangs", Annual Review of Anthropology, 32: $225-242$.

WHYTE, Willian Foote, 2005, Sociedade de Esquina. Rio de Janeiro, Jorge Zahar.

Identity and belonging: moral and disciplinary dispositions in a group of youngsters - Mauro Guilherme Pinheiro Koury - Universidade Federal da Paraíba; Grupo de Pesquisa em Antropologia e Sociologia das Emoções (GREM), Brasil • maurokoury@gmail.com

The article aims at the understanding of the sense of belonging and its relation with codes of trust and loyalty, categories here approached in the light of the fear of treason and individual uncertainty as to reaching the group's ideals. Research was developed among a group of youngsters auto-characterised as an organization for the support and affirmative action of the youngsters living in poor neighbourhoods in the city of João Pessoa, state of Paraíba, Brazil. The objective of this study was to understand the internal organizational process of the group and the binding networks that are the base for sociability within the group.

KEYWORDS: identity, trust, loyalty, moral dispositions, disciplinary dispositions, belonging. 